\title{
FORMATION AND DEVELOPMENT OF EXTERNAL STATE FINANCIAL CONTROL IN CONTEMPORARY RUSSIA
}

\author{
Izmodenov Andrei, Shaybakova Lyudmila* \\ Chair of Competition Law and Antimonopoly Regulation, Ural State University of Economics, 8 March / Narodnaya Volya st., 62/45, Ekaterinburg, \\ 620144, Russia \\ *Corresponding Author Email: econlaw@mail.ru
}

This is an open access article distributed under the Creative Commons Attribution License, which permits unrestricted use, distribution, and reproduction in any medium, provided the original work is properly cited.

\section{ARTICLE DETAILS}

\section{Article History:}

Received 12 March 2018 Accepted 12 April 2018 Available online 15 May 2018

\begin{abstract}
The article studies the process of external state financial control formation and development in the sphere of budget legal relations in the Russian Federation for the period from 1993 to 2017 based on an analysis of normative legal acts, monographs and documents relating to this period. The purpose of the study was to study the stages of formation and development of the Accounts Chamber of the Russian Federation and control and accounting bodies of the subjects of the Russian Federation. As a result of the research, conclusions are drawn about the subordination of these institutions to the legislative authorities of Russia, the multi-stage specification of the Russian Federation's legislation and their official status and authority, the official recognition of the separation of state financial control into external and internal, and sufficient institutional environment for effective work of the control and accounting bodies of the Russian Federation. Thus, the improvement of the legislation in the field of external financial control has made it possible to create a set of institutional units in Russia that control the effectiveness and rationality of using budgetary funds, and also contribute to suppressing corruption and plundering state resources.
\end{abstract}

\section{KEYWORDS}

Legislation, government, Financial Control, control and accounting bodies, the Accounts Chamber of the Russian Federation.

\section{INTRODUCTION}

The bodies of external state financial control, which are the Accounts Chamber of the Russian Federation and control and accounting bodies of the constituent entities of the Russian Federation, play a significant role in monitoring the use of public resources, the functioning of the state budget system, the legality and effectiveness of the formation and execution of budgets of all levels. The peculiarity of these bodies is that they are formed by legislative bodies, are accountable to them and are authorized to provide them with information on how effectively and efficiently the executive bodies of state power manage the financial resources of the state and regions. The bodies of external state financial control have gone through a difficult path from their formation to today's state, which fully meets international standards. To ensure this transformation allowed to improve the federal and regional legislation that regulates this activity.

\section{BACKGROUND}

\subsection{The main stages in the development of the regulatory and} legal framework for Russia's control and accounting system

The legal basis for state financial control in the budgetary sphere, which is carried out by the body formed by the parliament, is laid down in the Constitution of the Russian Federation, adopted by popular vote on December 12, 1993 [1]. The Constitution stipulates that the chambers of the Federal Assembly of the Russian Federation, the Federation Council and the State Duma, form the Accounts Chamber to monitor the execution of the federal budget, the composition and procedure of which are determined by federal law. The jurisdiction of the State Duma includes the appointment and dismissal of the Chairman of the Accounts Chamber and half of its auditors, the appointment and dismissal of the Deputy Chairman of the Accounts Chamber and the other half of its auditors came under the competence of the Federation Council.
In 1995, the Federal Law «On the Accounts Chamber of the Russian Federation» was adopted, which determined that the Accounts Chamber is a permanently operating body of state financial control formed by the Federal Assembly of the Russian Federation and accountable to it. The principles of the Chamber of Accounts proclaim legality, objectivity, independence and transparency. It consists of the chairman, his deputy, auditors and the staff of the Chamber of Accounts and is authorized to carry out control and audit, expert-analytical, information and other activities [2].

It should be noted that at that time the federal legislation regarding the regulation of state financial control did not fully comply with the guidelines for control enunciated in the Lima Declaration. Thus, this international document determines the need for the presence in the state of a higher supervisory body whose powers should be determined by the Constitution [3]. However, neither in the Constitution of the Russian Federation nor in the law on the Chamber of Accounts is it defined as the highest control body. The degree of independence of the Accounting Chamber is not fully understood. There is also no concept of external financial control.

Some shortcomings of the federal legislation did not prevent the creation of a constitutional body of financial control. The first meeting of the Board of the Accounting Chamber was held on April 18, 1995. Thus, it can be considered that in the spring of 1995 the Accounts Chamber of the Russian Federation was formed and started its activity.

At the same time, the legislative bodies of the constituent entities of the Russian Federation began to create the first financial control bodies accountable to them for the implementation of regional budgets. In May 1994, the Moscow City Duma adopted the City of Moscow Law «On the Control and Accounting Chamber of the Moscow City Duma». The law determined that the Control and Accounts Chamber of the Moscow City Duma was formed in the structure of the Duma and consisted of the 
chairman, deputy chairmen, experts of the Control and Accounting Chamber and its staff. By the Moscow City Law of November the 1st, 1995, the Control and Accounts Chamber of the Moscow City Duma was transformed into the Control and Accounting Chamber of Moscow. This body already had organizational independence, had the rights of a legal entity [4].

During 1995, the Parliaments of the constituent entities of the Russian Federation created 26 financial control bodies. In the absence of federal normative legal acts regulating the formation and functioning of such bodies, regional legislators created supervisory bodies both within the legislative (representative) bodies of the constituent entities of the Russian Federation and as independent bodies possessing the rights of a legal entity. These bodies had different degrees of independence, different structure and size, had different control powers and the possibilities of applying measures to violators of budget legislation and financial discipline.

By the end of 2000, the legislative bodies of the constituent entities of the Russian Federation had formed 67 control bodies, 32 of which were created as part of the legislative bodies of the constituent entities of the Russian Federation and 35 were independent legal entities [5]. The control bodies, created by regional parliaments, began to be called control and accounting bodies. In 2000, the association of control and accounting bodies of the Russian Federation (AKSOR) was established, and since 2006 the magazine «Vestnik AKSOR» has been published.

\subsection{Modern regulatory and legal framework of the Russian control and accounting system}

In 2000, the Budget Code of the Russian Federation came into force, which, inter alia, defined the basis for the implementation of state financial control in the budgetary sphere. The Code enshrined the right of regional legislatures to set up their own supervisory bodies to conduct external audit of budgets, authorized these monitoring bodies to conduct preliminary, current and subsequent monitoring, and carry out an external audit of budget performance reports. The wording used in the Budget Code did not answer many questions. The term «own control bodies» called into question the existence of a proper degree of independence for these bodies. The notion of control-counting bodies, practically applied for several years, was not fixed. Budgetary control was not divided into external and internal. The essence of external audit of budgets was not disclosed.

The qualitative change in the regulatory and legal framework for the implementation of state financial control in the budgetary sphere began in 2011 with the adoption of a federal law regulating the organization and operation of control and accounting bodies of the subjects of the Russian Federation and municipalities [6]. For the first time in the legislation, the wording «control and accounting bodies» appeared, for the first time they were called external public financial control bodies. This law established general requirements for the status, the process of forming, the composition and structure of the control and accounting bodies, the names of the main posts, formulated the forms of financial control, basic powers, the procedure for planning and implementing control activities. The law determined that the regional control and accounting bodies have organizational and functional independence, the rights of a legal entity, carry out their activities independently.

The adoption of this federal law has made it possible to introduce appropriate changes in the legislation of the Russian regions and ensure the creation during 2011 of control and accounting bodies that have organizational and functional independence in all constituent entities of the Russian Federation. There was an opportunity to unify the activities of regional bodies of external financial control on the basis of general principles set forth in the federal law. Standards of external state financial control began to be developed.

Particularly significant for the development of state financial control was 2013. A number of federal laws have been adopted that specify and extend the powers of the bodies of external state financial control. Federal Law № 41- Federal Law «On the Accounts Chamber of the Russian Federation» dated 05.04.2013 was adopted, in which it was given the status of the supreme body of external state financial audit (control), accountable to the Federal Assembly of the Russian Federation, which has organizational, functional and financial independence. As a state audit body, the Accounts Chamber of the Russian Federation was given the authority to conduct financial audit, performance audit, strategic audit, audit of state programs, investment projects, federal information systems, procurement audit, public debt audit, audit of the banking system of Russia [7]. Thus, in this law the views of S.V. Stepashin on the role of state audit in the development of the economy [8].

Federal Law № 44- Federal Law dated 05.04.2013 «On the Contract System in the Sphere of Procurement of Goods, Works and Services for Provision of State and Municipal Needs» authorized the Accounts Chamber of the Russian Federation, control and accounting bodies of the constituent entities of the Russian Federation to audit procurement, and evaluation of the results of procurement, achievement of procurement objectives [9]. The law clearly delineates the notion of control in the field of procurement and audit in the field of procurement [5].

Federal Law № 77- Federal Law «On Parliamentary Control» dated May the 7th, 2013, has drawn a line under the long-term discussion on whether the Accounts Chamber of the Russian Federation is a body of parliamentary control. The law determined that it is not a subject of parliamentary control, but only participates in its implementation, being «the supreme body of external state financial audit (control) reporting to the Federal Assembly of the Russian Federation» [10].

Federal Law № 252- Federal Law dated July 23, 2013 amended the Budget Code of the Russian Federation, which had a significant impact on improving the organization of state financial control in the budgetary sphere. The law established that state financial control is divided into external and internal. The external state financial control in the sphere of budgetary legal relations determines the control exercised by the Accounts Chamber of the Russian Federation, the control and accounting bodies of the subjects of the Russian Federation, internal control of the executive bodies of state power. The law outlines the basics of state financial control in the budgetary sphere - types, objects, methods of control, main powers of external and internal financial control bodies, documents drawn up following the results of control measures are defined [11].

Thus, by the end of 2013, the regulatory and legal framework for effective external state control in modern Russia has been formed, fully meeting the international principles set forth in the Lima Declaration. The Accounts Chamber of the Russian Federation, control and accounting bodies of the constituent entities of the Russian Federation received new opportunities for their development, using which they were able to improve the efficiency of their activities. At present, the bodies of external financial control function in all 84 constituent entities of the Russian Federation [12]. It should be noted that the establishment and development of control and accounting bodies of municipal entities was similarly carried out, but external municipal financial control is not the subject of this article.

\section{CONCLUSION}

Thus, by the end of 2013, the regulatory and legal framework for effective external state control in modern Russia has been formed, fully meeting the international principles set forth in the Lima Declaration. The Accounts Chamber of the Russian Federation, control and accounting bodies of the constituent entities of the Russian Federation received new opportunities for their development, using which they were able to improve the efficiency of their activities. At present, the bodies of external financial control function in all 84 constituent entities of the Russian Federation. It should be noted that the establishment and development of control and accounting bodies of municipal entities was similarly carried out, but external municipal financial control is not the subject of this article.

The improvement of the regulatory and legal framework had a crucial role in the formation and development of external state financial control in the sphere of budgetary legal relations in modern Russia and ensured the effective functioning of the Accounts Chamber of the Russian Federation and the control and accounting bodies of the constituent entities of the Russian Federation at the present time.

\section{ABOUT THE AUTHORS}

Izmodenov Andrei / Ural State University of Economics, Department of Competition law and antitrust legislation, associate professor. Research interests: state financial control, state audit, financial law. Shaybakova Lyudmila. Ural State University of Economics, Department of Competition law and antitrust legislation, Doctor of Economics, Professor. Research interests: innovation development, innovation policy, innovation infrastructure, innovation management.

\section{REFERENCES}

[1] The Constitution of the Russian Federation. 1993 http://www.constitution.ru/en/10003000-01.htm. 
[2] Federal Law of 11.01.1994 № 4- FL «On the Accounts Chamber of the Russian Federation» http://www.ach.gov.ru/en/.

\section{[3] Lima Declaration of Control Guidelines. 2016.} http://www1.worldbank.org/publicsector/pe/befa05/LimaDeclaration. pdf.

[4] The official site of the Control and Accounting Chamber of Moscow. Retrieved from http:// www.ksp.mos.ru.

[5] Izmodenov, A.K., Franz, O.B., Shaibakova, L.F. 2017. Audit and control in the sphere of procurement of goods, works, services for provision of state and municipal needs. Competitiveness in the global world: economy, science, technology, 6 (5), 32-34.

[6] Federal Law of 07.02.2011 № 6- FL «On the General Principles of the Organization and Activity of the Control and Accounting Bodies of the Subjects of the Russian Federation and Municipal Formations».
[7] Federal Law of 04/05/2013 № 41- FL «On the Accounts Chamber of the Russian Federation».

[8] Stepashin, S.V. 2008. State Audit and the Future Economics. M.: Nauka

[9] Federal Law of 05.04.2013 № 44- FL «On the Contract System in the Sphere of Procurement of Goods, Works, and Services for Ensuring State and Municipal Needs».

[10] Federal Law of 07.05.2013 № 77- FL «On parliamentary control».

[11] Federal Law of July 23, 2013 № 252- FL «On Amendments to the Budget Code of the Russian Federation and Certain Legislative Acts of the Russian Federation».

[12] Kolesov, R.V., Yurchenko, A.V. 2013. System of state financial control of the Russian Federation: problems and prospects: Monograph. Yaroslavl: JF MFBA. 